\title{
Saluting Robert A. Gross
}

\section{Editor nonpareil}

Patricia K. Baskin, MS

Neurology ${ }^{\circledR}$ 2020;94:555-556. doi:10.1212/WNL.0000000000009231
Correspondence

P.K. Baskin

pbaskin@neurology.org
Robert A. Gross, MD, PhD, FANA, FAAN, the retiring Editor-in-Chief (EIC), has served as an Associate Editor (under former Editor-in-Chief Robert C. Griggs, MD, FAAN), Deputy Editor (under John H. Noseworthy, MD, FAAN), and finally EIC of Neurology ${ }^{\circledR}$ at a turbulent and uncertain time for the scholarly publishing industry. During the 19-year period in which he held these roles, scientific journals proliferated at a rapid rate and the electronic journal came into its own as the canonical version of research articles published. Electronic tracking systems and reviewer databases became the norm. A new business model, open access, appeared, threatening the existence of the subscription model and the publishing world as we knew it. Indeed, publication of scientific material on the world wide web, with the advent of post-peer review journals and preprint servers, threatened the long-held tradition of blinded peer review. The insertion of predatory publishers in the mix complicated article publishing even further.

As an Associate Editor and Deputy Editor, Dr. Gross contributed to the discussions and decisions relating to critical policies developed before he began his tenure as EIC. These policies included authorship policies to avoid ghostwriting, mandating that all authors declare all sources of possible bias, and assignments of classification of evidence criteria for therapeutic and diagnostic papers. The onset of his term marked the beginning of a cascade of highly innovative developments that would follow throughout his tenure.

It was my pleasure to work under the leadership of Dr. Gross during this time, keeping abreast of developments in publishing through publishing industry meetings and contacts, and bringing industry initiatives to him and his team of editors. Our annual editorial retreats regularly included presentations from industry leaders in scholarly publishing as well as speakers from other high-impact biomedical journals, propelling discussions leading to the next innovation for the journal. Retreats centered around the topics of spinning off subspecialty journals; publishing articles after they had been published on preprint servers; publishing peer reviews, short forms, and other derivatives of articles along with expanded and more data-rich articles; availability and sharing of data; better website and print design; and in general reimagining the journal to make it more reader-centric, that is, more relevant and easier to read for today's busy practitioner. Dr. Gross was always eager to pursue new ideas about how to improve the quality of the journal and make its content more valuable to practitioners and researchers alike.

The journal staff has been fortunate to see the personal side of Dr. Gross as a consequence of our interactions with him during the many retreats, editorial meetings at the American Academy of Neurology (AAN), and numerous other visits over the years of his tenure. On those occasions, we enjoyed hearing his enthusiasm for attending a baseball game that coincides with the annual meeting in a city with a major league team, searching for the perfect cup of coffee since a recent trip to Italy made him a coffee afficionado, finally gaining a daughter when the older of his 2 sons recently married, and sampling whiskies or looking for the ultimate Negroni cocktail when with his wife Marsha on a trip to Scotland. And, of course, we never saw him without a bow tie 
(he never wears any other type); a few years ago, he even made a video of how to tie one for the AAN store.

Thank you, Dr. Gross, for your long years of service to the journal and for your leadership. We will miss you.

\section{Study funding}

No targeted funding reported.

\section{Disclosure}

P.K. Baskin is Executive Editor of the Neurology ${ }^{\circledR}$ journals and employed by the American Academy of Neurology; she consulted with no stipend or reimbursements for the Medical Publishing Insights and Practices initiative, served as Editorin-Chief of Science Editor, and is Past-President of the Council of Science Editors. 


\title{
Neurology
}

\author{
Saluting Robert A. Gross: Editor nonpareil \\ Patricia K. Baskin \\ Neurology 2020;94;555-556 \\ DOI 10.1212/WNL.0000000000009231
}

This information is current as of March 30, 2020

$\begin{array}{ll}\begin{array}{l}\text { Updated Information \& } \\ \text { Services }\end{array} & \begin{array}{l}\text { including high resolution figures, can be found at: } \\ \text { http://n.neurology.org/content/94/13/555.full }\end{array} \\ \text { Permissions \& Licensing } & \begin{array}{l}\text { Information about reproducing this article in parts (figures,tables) or in } \\ \text { its entirety can be found online at: } \\ \text { http://www.neurology.org/about/about_the_journal\#permissions }\end{array} \\ & \begin{array}{l}\text { Information about ordering reprints can be found online: } \\ \text { http://n.neurology.org/subscribers/advertise }\end{array}\end{array}$

Neurology ${ }^{\circledR}$ is the official journal of the American Academy of Neurology. Published continuously since 1951, it is now a weekly with 48 issues per year. Copyright (C 2020 American Academy of Neurology. All rights reserved. Print ISSN: 0028-3878. Online ISSN: 1526-632X.

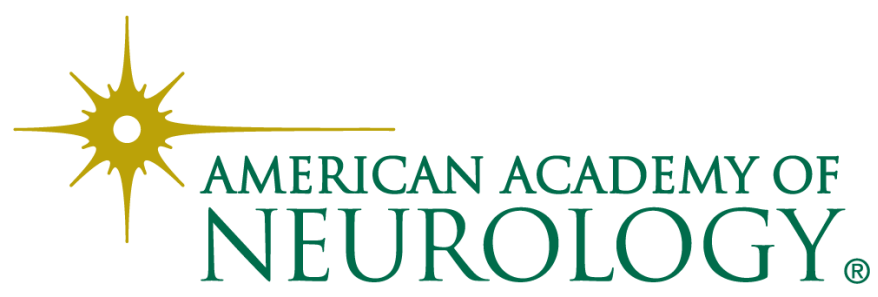

